\title{
ANESTESIOLOGIA
}

\section{Fatal Recrudescence of Malignant Hyperthermia in an Infant with Moebius Syndrome}

\author{
Cláudia Regina Fernandes* 2, Washington Aspiculeta Pinto Filho ${ }^{1}$, \\ Lia Cavalcante Cezar ${ }^{3}$, Josenília Maria Alves Gomes ${ }^{4}$, \\ Glauco Kleming Florencio da Cunha ${ }^{5}$
}

1. TSA; PhD; Professor of Medicine, Universidade de Fortaleza (Unifor); Responsible for CET/MEC/SBA, Hospital Universitário Walter Cantídio, Universidade Federal do Ceará (UFC), Fortaleza, Ceará, Brazil 2. TSA; Co-responsible for CET/MEC/SBA, Hospital Universitário Walter Cantídio, UFC; Anesthesiologist, Hospital Infantil Albert Sabin, Secretary of Health of Ceará, Fortaleza, Ceará, Brazil

3. Medical specialization in Anesthesiology, CET/MEC/ SBA, Hospital

Universitário Walter Cantídio, UFC, Fortaleza, Ceará, Brazil

4. TSA; PhD; Professor of Medicine, UFC; Pedagogical Supervisor of the Medical Course at Unifor; Responsible for CET/MEC/SBA, Oziel de Sousa Lima, Santa Casa de Misericordia de Sobral, UFC, Fortaleza, Ceará, Brazil 5. TSA; Masters in Public Health, Universidade Estadual do Ceará; Co-responsible for CET / MEC / SBA, University Hospital Walter Cantídio, UFC, Chief of Surgical Theatre, Hospital Infantil Albert Sabin, Fortaleza, Ceará, Brazil Received from Universidade de Fortaleza (Unifor), Fortaleza, Ceará, Brazil.

Submitted on April 7, 2012. Approved on June 12, 2012.

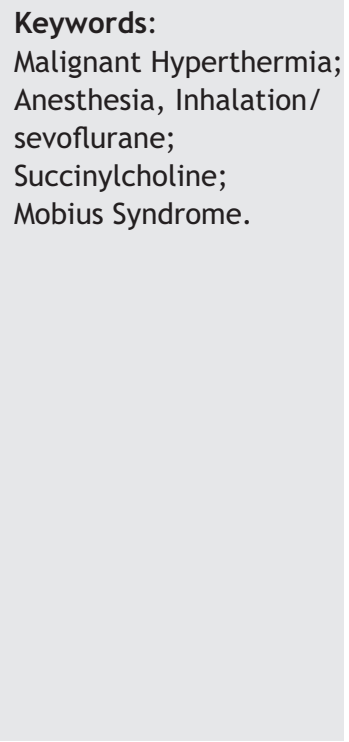

\begin{abstract}
Background and objectives: Malignant hyperthermia $(\mathrm{MH})$ is a pharmacogenetic skeletal muscle disorder characterized by a hypermetabolic state after anesthesia with succinylcholine and/ or volatile anesthetics. Various neuromuscular syndromes are associated with susceptibility; however, Moebius syndrome has not been reported. Dantrolene is the drug of choice for treatment. Recurrence may occur in up to $20 \%$ of cases after the initial event treatment.

Case Report: Male infant, first twin, 7 months old, weighing $6.5 \mathrm{~kg}$ and presenting with Moebius syndrome was admitted for clubfoot repair. The patient had $\mathrm{MH}$ after exposure to sevoflurane and succinylcholine, which was readily reversed with dantrolene maintained for 24 hours. Ten hours after dantrolene discontinuation, there was recrudescence of $\mathrm{MH}$ that did not respond satisfactorily to treatment, and the patient died.

Discussion: Musculoskeletal disorders in children are associated with increased risk of developing $\mathrm{MH}$, although Moebius syndrome has not yet been reported. Dantrolene is the drug of choice for treating this syndrome; prophylaxis is indicated during the first 24-48 hours of the episode onset. The main risk factors for recurrence are muscular type, long latency after anesthetic exposure, and increased temperature. The child had only one risk factor. This case leads us to reflect on how we must be attentive to children with musculoskeletal disease and maintain treatment for 48 hours.
\end{abstract}

๑ 2013 Sociedade Brasileira de Anestesiologia. Published by Elsevier Editora Ltda. All rights reserved.

*Corresponding author: E-mail: clauregifer@gmail.com

ISSN/\$ - see front metter ๔ 2013 Sociedade Brasileira de Anestesiologia. Published by Elsevier Editora Ltda. All rights reserved. 


\section{Introduction}

Malignant hyperthermia $(\mathrm{MH})$ is a hereditary pharmacogenetic skeletal muscle disorder characterized by a hypermetabolic state after anesthesia with succinylcholine and/or volatile anesthetics ${ }^{1-3}$.

The initial diagnosis is clinical, mainly characterized by tachycardia and increased end-tidal carbon dioxide. In the late phase, there is rapid increase in body temperature and extreme acidosis, marked by loss of intracellular calcium ion levels and uncontrolled increase in skeletal muscle metabolism, which may progress to severe rhabdomyolysis ${ }^{4}$.

In the 1980s, the caffeine-halothane contracture test became the gold standard diagnostic test for $\mathrm{MH}$ and a variety of neuromuscular disorders associated with susceptibility to this syndrome. Duchenne muscular dystrophy, congenital myotonia, myotonic dystrophy, nonspecific myopathies, central core disease, King Denborough syndrome, osteogenesis imperfecta, and Schwartz-Jampel syndrome were reported $^{5}$.

Incidence and prevalence of $\mathrm{MH}$ are variable, with no difference regarding gender or ethnicity. The incidence varies with age: approximately $1: 50,000$ in adults and 1:15,000 in children ${ }^{6-10}$.

The pathophysiological mechanism is associated with ryanodine receptor type-1 (RYR1) mutation, which is responsible for calcium release from the sarcoplasmic reticulum. Mutation in RYR1 is found in approximately $50 \%$ of the susceptible families ${ }^{11-13}$.

The occurrence of $\mathrm{MH}$ is seen in the first or in subsequent exposures to halogenated agents ${ }^{14,15}$.

Currently, dantrolene remains the primary basis for the successful management of $\mathrm{MH}^{16,17}$.

The syndrome recrudescence may occur in up to $20 \%$ of cases, mostly within 16 hours of the clinical condition onset ${ }^{18}$.

Moebius syndrome is a rare disorder, characterized by unilateral or bilateral facial paralysis and extraocular movements defects, secondary to congenital paralysis of the facial (VII) and abducens (VI) nerves ${ }^{19,20}$. It is followed by other cranial nerve dysfunctions, orofacial abnormalities, musculoskeletal hypotonia, and orthopedic anomalies, including clubfoot ${ }^{21}$.

To date, there is no report in literature on the association between Moebius syndrome and malignant hyperthermia. The aim of this study was to report a case of malignant hyperthermia in an infant with Moebius syndrome, as well as its management and outcome.

\section{Case Report}

Male infant, first twin, 7 months old, weighing $6.5 \mathrm{~kg}$, presenting a history of prematurity (born at 34 weeks gestation) and Moebius syndrome. He was admitted for surgical repair of clubfoot and showed development consistent with his age. Laboratory tests were normal. The patient did not undergo prior surgery, and there were no reports of complications with general anesthesia in the family. On arrival to the operating room, the patient was monitored with ECG, pulse oximetry, and noninvasive blood pressure. After preoxygenation for 5 minutes, inhalational induction with sevoflurane 3\% was started, followed by venoclysis. Soon after exposure to the halogenated anesthetic agent, the infant had hypertonia and agitation, which was interpreted as absence of anesthetic plan. For management, the concentration of sevoflurane was increased to $8 \%$, followed by administration of atropine $\left(20 \mathrm{mcg} . \mathrm{kg}^{-1}\right)$ and muscle relaxation with succinylcholine $\left(1 \mathrm{mg} . \mathrm{kg}^{-1}\right)$, resulting in additional hypertonia, generalized muscle contraction including masseter muscle, which prevented tracheal intubation and impaired the ventilation by mask, with consequent desaturation. The hypothesis of $\mathrm{MH}$ was suggested, sevoflurane was discontinued, and rocuronium (1 mg. $\left.\mathrm{kg}^{-1}\right)$ was administered in order to facilitate tracheal intubation. The child was intubated and the surgery canceled. The patient was monitored with $\mathrm{P}_{\mathrm{ET}} \mathrm{CO}_{2}$, axillary temperature, and blood pressure measurements. In the first 10 minutes after exposure to the triggering agents, there was a progressive increase of $\mathrm{P}_{\mathrm{ET}} \mathrm{CO}_{2}$ (levels near 80 $\mathrm{mm} \mathrm{Hg}$ ), despite hyperventilation; tachycardia (rate of 150 bpm, evolving to $180 \mathrm{bpm})$; hypertension $(120 / 80 \mathrm{~mm} \mathrm{Hg})$, even with the use of midazolam $\left(0.1 \mathrm{mg}^{\mathrm{kg}} \mathrm{k}^{-1}\right)$. After $20 \mathrm{mi}-$ nutes of the event occurrence, hyperthermia $\left(T=38^{\circ} \mathrm{C}\right)$ was observed. Laboratory tests were performed (arterial blood gases and electrolytes), and general and specific measures for $\mathrm{MH}$ were established.

Ringer lactate was administered with $1 \%$ glucose $(20$ $\mathrm{mL} . \mathrm{kg}^{-1}$ ) and cooling performed with physical means (aircooling system, cold pads, and cold serum). The patient was hyperventilated with $\mathrm{O}_{2}(100 \%)$, reducing $\mathrm{P}_{\mathrm{ET}} \mathrm{CO}_{2}$ to $45 \mathrm{~mm} \mathrm{Hg}$. After measurement of arterial blood gases and electrolytes (Table 1), mixed metabolic acidosis associated with hyperkalemia was diagnosed, and $\mathrm{NaHCO}_{3}$ 8.4\% (1 mEq. $\left.\mathrm{kg}^{-1}\right)$, calcium gluconate $10 \%\left(20 \mathrm{mg} \cdot \mathrm{kg}_{-1}\right)$, and bolus of Ringer lactate $\left(20 \mathrm{~mL}^{\mathrm{kg}}{ }^{-1}\right)$ were administered. Specific treatment for $\mathrm{MH}$ was performed with dantrolene $\left(2.5 \mathrm{mg}^{\mathrm{kg}}{ }^{-1}\right)$, which occurred approximately 60 minutes after the onset of signs and symptoms.

Overall condition improvement was observed after dantrolene administration. The intubated and sedated infant was taken to the Intensive Care Unit (ICU). Dantrolene was prescribed at doses of $1 \mathrm{mg} \cdot \mathrm{kg}-{ }^{1}$ every $6 \mathrm{~h}$. Laboratory tests as response curve were performed to assess the degree of muscle destruction, blood gas, and electrolytes (Table 2). ICU baseline clinical parameters were satisfactory. Hyperthermia, tachycardia, hypertension or desaturation were not observed.

The patient developed respiratory failure, with $\mathrm{SatO}_{2}$ up to $80 \%$, despite $\mathrm{FiO}_{2}$ of $100 \%$, proper ventilation, and no changes in chest X-ray. New laboratory tests (Table 3 ) were

Table 1 Arterial blood gases and electrolytes.

\begin{tabular}{llll}
\hline Blood gas & \multicolumn{3}{c}{ Electrolytes } \\
\hline $\mathrm{pH}$ & 7.17 & $\mathrm{Na}+$ & $139.7 \mathrm{mEq} \cdot \mathrm{L}^{-1}$ \\
$\mathrm{pCO}_{2}$ & $55.7 \mathrm{mmHg}$ & $\mathrm{K}+$ & $5.1 \mathrm{mEq} \cdot \mathrm{L}^{-1}$ \\
$\mathrm{pO}_{2}$ & $297 \mathrm{mmHg}$ & Blood glucose & $334 \mathrm{mg} . \mathrm{dL}^{-1}$ \\
$\mathrm{SatO}_{2}$ & $99 \%$ & & \\
$\mathrm{HCO}_{3}{ }^{-}$std & $17.4 \mathrm{mEq} \cdot \mathrm{L}^{-1}$ & \\
$\mathrm{BE}$ & $(-8.6)$ & \\
\hline
\end{tabular}

BE: Base Excess. 
Table 2 Laboratory tests - response curve during Intensive Care (ICU) stay.

\begin{tabular}{|c|c|c|}
\hline Tests & ICU Admission & $24 \mathrm{~h}$ after ICU admission \\
\hline $\mathrm{pH}$ & 7.37 & 7.4 \\
\hline $\mathrm{pO}_{2}$ & $135 \mathrm{~mm} \mathrm{Hg}$ & $132.8 \mathrm{~mm} \mathrm{Hg}$ \\
\hline $\mathrm{pCO}_{2}$ & $45.1 \mathrm{~mm} \mathrm{Hg}$ & $40 \mathrm{~mm} \mathrm{Hg}$ \\
\hline $\mathrm{HCO}_{3}$ & $25.5 \mathrm{mg} \cdot \mathrm{dL}^{-1}$ & $24 \mathrm{mg} \cdot \mathrm{dL}^{-1}$ \\
\hline $\mathrm{SatO}_{2}$ & $98 \%$ & $98 \%$ \\
\hline $\mathrm{Na}+$ & $136 \mathrm{mEq} \cdot \mathrm{L}^{-1}$ & $136 \mathrm{mEq} \cdot \mathrm{L}^{-1}$ \\
\hline $\mathrm{K}+$ & $5.1 \mathrm{mEq} \cdot \mathrm{L}^{-1}$ & $3.17 \mathrm{mEq} \cdot \mathrm{L}^{-1}$ \\
\hline $\mathrm{Ca}++$ & $9.6 \mathrm{mg} \cdot \mathrm{dL}^{-1}$ & \\
\hline GOT & $78 U^{U} . L^{-1}$ & 50 U.L-1 \\
\hline GPT & 23 U U.L.-1 & $25 U^{U} . L^{-1}$ \\
\hline LDH & 1691 U.L.-1 & \\
\hline ALP & 452 U.L-1 & \\
\hline CPK & 524 U. $L^{-1}$ & 323 U.L-1 \\
\hline Glicemia & $524 \mathrm{mg} \cdot \mathrm{dL}^{-1}$ & $118 \mathrm{mg} \cdot \mathrm{dL}^{-1}$ \\
\hline
\end{tabular}

GOT: Glutamic oxaloacetic transaminase; GPT: Glutamic pyruvic transaminase; ALP: Alkaline phosphatase; CPK: creatine phosphokinase; LDH: Lactate dehydrogenase.

Table 3 Evolution of arterial blood gases and electrolytes.

\begin{tabular}{llll}
\hline $\begin{array}{l}\text { Arterial } \\
\text { blood gas }\end{array}$ & \multicolumn{3}{c}{ Electrolytes } \\
\hline $\mathrm{pH}$ & 6,8 & $\mathrm{Na}+$ & $122 \mathrm{mEq} \cdot \mathrm{L}^{-1}$ \\
$\mathrm{pCO}_{2}$ & $91 \mathrm{~mm} \mathrm{Hg}$ & $\mathrm{K}+$ & $6.6 \mathrm{mEq} \cdot \mathrm{L}^{-1}$ \\
$\mathrm{pO}_{2}$ & $113 \mathrm{~mm} \mathrm{Hg}$ & Blood Glucose & $425 \mathrm{mg} \cdot \mathrm{dL}^{-1}$ \\
$\mathrm{SatO}_{2}$ & $99 \%$ & & \\
$\mathrm{HCO}_{3}$ - std & $31 \mathrm{mEq} \cdot \mathrm{L}^{-1}$ & \\
$\mathrm{BE}$ & $(-) 6$ & \\
\hline
\end{tabular}

BE: Base Excess.

performed and arterial blood gases showed significant respiratory acidosis, hyperkalemia, and hyperglycemia. He evolved with cardiac arrhythmias (extrasystoles), desaturation, and bradycardia with cardiopulmonary arrest (CA). CA protocol was applied and dantrolene $\left(1 \mathrm{mg} \cdot \mathrm{kg}^{-1}\right)$ reintroduced, without success, and the patient died due to asystolic CA.

\section{Discussion}

$\mathrm{MH}$ is a potentially fatal medical condition. The Clinical Grading Scale criteria to predict $\mathrm{MH}$ are: respiratory acidosis characterized by end-tidal $\mathrm{CO}_{2}\left(\mathrm{ETCO}_{2}>55 \mathrm{~mm} \mathrm{Hg}\right) ; \mathrm{PaCO}_{2}>$ $60 \mathrm{~mm} \mathrm{Hg}$ observed in arterial blood gas; unexplained cardiac manifestation characterized by sinus tachycardia, ventricular tachycardia or ventricular fibrillation; metabolic acidosis with a base deficit $>8 \mathrm{mEq} . \mathrm{L}^{-1} ; \mathrm{pH}<7.25$; generalized muscle rigidity; severe masseter muscle rigidity; muscle lysis represented by serum creatine phosphokinase (CPK > 20,000 U.L-1); dark urine; increased myoglobin levels in plasma or urine; plasma potassium $>6 \mathrm{mEq} . \mathrm{L}^{-1}$; rapid rise of temperature; temperature $>38.8^{\circ} \mathrm{C}$; rapid reversal of $\mathrm{MH}$ signs with dantrolene administration; elevated serum concentration of creatine phosphokinase at rest; family history consistent with autosomal dominant inheritance ${ }^{22}$. The case presented here had the classical clinical diagnostic criteria for $\mathrm{MH}$.

In an American study assessing 286 cases of $\mathrm{MH}$ between 1987 and 2006, it was found that the most frequently manifested clinical signs were: hypercarbia (92.2\%), sinus tachycardia (72.9\%), rapid increase in core body temperature $(64.7 \%)$, generalized muscle rigidity $(40.8 \%)$, masseter spasm $(26.7 \%)$, and sweating $(17.6 \%)^{23}$. This clinical signs were present in the infant in question.

The main point of the management and treatment of an acute crisis is the immediate discontinuation of the triggering agent, followed by hyperventilation associated with administration of dantrolene $\left(2.5 \mathrm{mg} . \mathrm{kg}^{-1}\right)$, which can be repeated until the $\mathrm{MH}$ crisis is aborted. The suggested dose limit of dandrolene is 10 mg. $\mathrm{kg}^{-1}$, which may be increased depending on the case. Cooling measures should be started and arrhythmias treated; do not use calcium channel blockers; perform blood tests (blood gas, electrolytes, creatine phosphokinase, myoglobin plasma and urine, coagulation profile should be checked every 6 to 12 hours); hyperkalemia should be treated when indicated; continue dantrolene at a dose of $1 \mathrm{mg} . \mathrm{kg}^{-1}$ every 4 to 8 hours for 24 to 48 hours. The desired urine output is $2 \mathrm{~mL} . \mathrm{kg} \cdot \mathrm{min}^{-1}$, which can be stimulated with mannitol, furosemide and fluids, if necessary; assess the need for invasive monitoring and mechanical ventilation; observe the patient in the ICU for at least 36 hours. It is recommended to refer the patient and family to an $\mathrm{MH}$ testing center for contracture or DNA test. Patients affected by $\mathrm{MH}$ must receive dantrolene and be closely monitored for 48 to 72 hours, as even with dantrolene treatment, $20 \%$ of patients may experience recrudescence of the symptoms ${ }^{18,22}$.

In the case described here, all recommendations were followed. Dantrolene was administered every 6 hours during the 24 hours following the initial episode, as recommended in the literature, but recrudescence occurred 10 hours after drug treatment discontinuation.

Laboratory evaluation after the event should include testing for disseminated intravascular coagulation (DIC), as well as the observation of myoglobinuria and renal function. DIC is more frequent when the body temperature exceeds $41^{\circ} \mathrm{C}^{22}$. In the case described, muscle lysis was not intense, as seen on the initial tests, and there was no myoglobinuria, probably because treatment was started early.

Currently, dantrolene is the only treatment specific for $\mathrm{MH}$. Because this syndrome present with nonspecific signs and treatment delay results in life-threatening outcome, this drug should be administered as soon as MH is suspected. However, dantrolene does not come without its complications - hepatotoxicity is one of its potential adverse effects ${ }^{15,24}$. In an analysis of 368 patients who received dantrolene for $\mathrm{MH}$ treatment, the most frequent complications were muscle 
weakness $(21.7 \%)$, phlebitis $(9 \%)$, gastrointestinal discomfort (4.1\%), and respiratory failure $(3.8 \%)^{25}$. There are reports of apnea in newborns and infants after using this drug ${ }^{26,27}$.

Due to the potential toxicity of dantrolene and its respiratory depression effect on infants, in addition to complications associated with prolonged mechanical ventilation ${ }^{28}$, dantrolene discontinuation was decided after 24 hours. Unfortunately, the syndrome recrudescence occurred 10 hours after treatment discontinuation.

Recrudescence is defined as the development of $\mathrm{MH}$ signs 2 hours after the initial episode treatment. Recrudescence clinical signs include increased heart rate, minute ventilation to maintain $\mathrm{PaCO}_{2}$, and temperature. In a case-control study, data from 308 patients with HM were collected, 63 in the recrudescent group and 245 in the control group. Recrudescence occurred between 2.5 and 72 hours after the $\mathrm{MH}$ episode, with $80 \%$ occurring at the first 16 hours. The three main factors associated with recrudescence were muscular type, HM episode long latency after induction of anesthesia, and increased temperature ${ }^{18}$. The infant in the case reported here had only one risk factor for recrudescence (increased temperature at the time of the initial episode), which occurred 36 hours after the initial episode and 10 hours after discontinuation of treatment with dantrolene.

Because MH has a strong genetic character, and the patient reported here was a monochorionic twin, contracture test in the other twin would be extremely beneficial in diagnosing the syndrome. However, the non-recommendation of this diagnostic test in children weighing less than $20 \mathrm{~kg}$ prevents its realization ${ }^{29}$. Thus, clarifying and counseling the family were adopted as a means of preventing morbidity in the other twin.

In a study assessing quantitatively the existence of comorbidities and $\mathrm{MH}$ diagnosis, it was found that compared with the general pediatric population, children diagnosed with MH had significant comorbidities, such as musculoskeletal system and connective tissue diseases, circulatory system diseases, and congenital anomalies. The specific diagnosis most strongly associated with $\mathrm{MH}$ was muscular dystrophy ${ }^{30}$. The child described here had a musculoskeletal syndrome, which corroborates the findings of the above-mentioned study.

After consideration on the case, we understand that close attention should be paid to children with comorbid conditions, particularly musculoskeletal syndromes and muscular dystrophies. We understand the importance of dantrolene administration for a time exceeding 24 hours; the need for a better understanding of this syndrome by anesthesiologists, intensive care team, and other professionals; and that the possibility of $\mathrm{MH}$ recrudescence should always be considered. Moreover, the availability of dantrolene in all hospitals is essential for managing cases, as well as research development for new drugs specific for $\mathrm{MH}$, such as azumolene, possibly less toxic ${ }^{31}$.

\section{References}

1. Denborough M - Malignant hyperthermia. Lancet. 1998;3:11311136.

2. Stratman RC, Flynn JD, Hatton KW - Malignant hyperthermia: a pharmacogenetic disorder. Orthopedics. 2009;32:835.
3. Uchoa RB, Fernandes CR - Rabdomiólise induzida por exercício e risco de hipertermia maligna. Relato de caso. Rev Bras Anestesiol. 2003;53:63-68.

4. Denborough MA - Malignant hyperthermia. Anesthesiology. 2008;108:156-157.

5. Heiman-Patterson TD, Rosenberg H, Fletcher JE et al. Halothane-caffeine contracture testing in neuromuscular diseases. Muscle Nerve. 1988;11:453-457.

6. Sumitani M, Uchida K, Yasunaga $\mathrm{H}$ et al. - Prevalence of malignant hyperthermia and relationship with anesthetics in Japan: data from the diagnosis procedure combination database. Anesthesiology. 2011;114:84-90.

7. Brady JE, Sun LS, Rosenberg $\mathrm{H}$ et al. - Prevalence of malignant hyperthermia due to anesthesia in New York State, 2001-2005. Anesth Analg. 2009;109:1162-1166.

8. Ording $\mathrm{H}$ - Incidence of malignant hyperthermia in Denmark. Anesth Analg. 1985;64:700-704.

9. Pollock AN, Langton EE, Couchman K et al. - Suspected malignant hyperthermia reactions in New Zealand. Anaesth Intensive Care. 2002;30:453-461.

10. Simões CM, Koishi GN, Rozatti M et al. - Estamos preparados para diagnosticar e conduzir um episódio de hipertermia maligna? Rev Bras Anestesiol. 2003;53:248-257.

11. Carpenter $D$, Ringrose $C$, Leo $V$ et al. The role of CACNA1S in predisposition to malignant hyperthermia. BMC Med Genet. 2009;10:104.

12. Carpenter D, Morris A, Robinson RL et al. Analysis of RYR1 haplotype profile in patients with malignant hyperthermia. Ann Hum Genet. 2009;73:10-18.

13. Lanner JT. Ryanodine receptor physiology and its role in disease. Adv Exp Med Biol. 2012;740:217-234.

14. Chen PL, Day YJ, Su BC et al. - Delayed onset of sevofluraneinduced juvenile malignant hyperthermia after exposure. Acta Anaesthesiol Taiwan. 2007;45:189-193.

15. Fernandes CR, Azevedo DM, Gomes JM et al. - Malignant hyperthermia in a liver transplant patient: a case report. Transplant Proc. 2007;39:3530-3532.

16. Krause T, Gerbershagen MU, Fiege M et al. - Dantrolene: a review of its pharmacology, therapeutic use, and new developments. Anaesthesia. 2004;59:364-373.

17. Inan S, Wei H - The cytoprotective effectsof dantrolene: a ryanodine receptor antagonist. Anesth Analg. 2010;111:1400410.

18. Burkman JM, Posner KL, Domino KB - Analysis of the clinical variables associated with recrudescence after malignant hyperthermia reactions. Anesthesiology. 2007;106:901-906.

19. Gondipalli P, Tobias JD - Anesthetic implications of Möbius syndrome. J Clin Anesth. 2006;18:55-59.

20. Hobaika AB, Neves BS, Fernandes ML et al. - Anestesia para paciente portador da síndrome de Moebius. Relato de caso. Rev Bras Anestesiol. 2009;59:341-343.

21. Almeida MBV, Brandt CT, Lima JA et al. - A incidência de anomalias ortopédicas em portadores da síndrome de Moebius e sua associação com o uso do misoprostol. Rev Bras Ortop. 2007; 42:10-16.

22. Rosenberg H, Davis M, James D et al. - Malignant hyperthermia. Orphanet J Rare Dis. 2007;24;2:21.

23. Larach MG, Gronert GA, Allen GC et al. - Clinical presentation, treatment, and complications of malignant hyperthermia in North America from 1987 to 2006. Anesth Analg. 2010;110:498507.

24. Fernandes CR, Marinho DS, Cavalcante FP. - Malignant hyperthermia in liver transplantation. In: Abdeldayem $\mathrm{H}$, Allam N. Liver transplantation - Basic issues. Rijeka: Intech, 2012;397418. 
25. Brandom BW, Larach MG, Chen MS et al. - Complications associated with the administration of dantrolene 1987 to 2006: a report from the North American Malignant Hyperthermia Registry of the Malignant Hyperthermia Association of the United States. Anesth Analg. 2011;112:1115-1123.

26. Pollock N, Langtont E, Stowell K et al. - Safe duration of postoperative monitoring for malignant hyperthermia susceptible patients. Anesth Intensive Care. 2004;32:502-509.

27. Lerman J, McLeod ME, Strong HA - Pharmacokinetics of intravenous dantrolene in children. Anesthesiology. 1989;70:625629.
28. Monteverde E, Fernández A, Poterala R et al. - Characterization of pediatric patients receiving prolonged mechanical ventilation. Pediatr Crit Care Med. 2011;12:287-91.

29. Maccani RM, Wedel DJ, Melton A et al. - Femoral and lateral femoral cutaneous nerve block for muscle biopsies in children. Paediatr Anaesth. 1995;5:223-227.

30. Li G, Brady JE, Rosenberg H et al. - Excess comorbidities associated with malignant hyperthermia diagnosis in pediatric hospital discharge records. Paediatr Anaesth. 2011;21:958-963.

31. Sudo RT - Effects of azumolene on normal and malignant hyperthermia-susceptible skeletal muscle. Basic Clin Pharmacol Toxicol. 2008;102:308-316. 